\title{
Biohydrogen and Biomethane (Biogas) Production in the Consecutive Stages of Anaerobic Digestion of Molasses
}

\author{
Anna Detman ${ }^{1}$, Aleksandra Chojnacka ${ }^{1}$, Mieczysław Błaszczyk ${ }^{2}$, \\ Wiktor Kaźmierczak ${ }^{1}$, Jan Piotrowski ${ }^{3}$, Anna Sikora ${ }^{1 *}$ \\ ${ }^{1}$ Institute of Biochemistry and Biophysics, Polish Academy of Sciences, \\ Pawińskiego 5a, 02-106 Warsaw, Poland \\ ${ }^{2}$ Faculty of Agriculture and Biology, Warsaw University of Life Sciences, \\ Nowoursynowska 159, 02-776 Warsaw, Poland \\ ${ }^{3}$ Krajowa Spółka Cukrowa S.A. Biuro w Warszawie, \\ Jana Pawła II 12, 00-124 Warsaw, Poland
}

Received: 27 October 2016

Accepted: 29 December 2016

\begin{abstract}
Anaerobic digestion, whose final products are methane and carbon dioxide, has been used to produce biogas from waste biomass as an alternative energy source. For the purpose of innovative, modern technologies based on microbial processes, it is desirable to separate the hydrogen- (hydrolysis and acidogenesis) and methane-yielding (acetogenesis and methanogenesis) stages of anaerobic digestion to respectively favor the production of hydrogen and methane under controlled conditions. Previously, we developed a benchscale (3- and 3.5-litre bioreactors) two-stage anaerobic digestion system producing hydrogen (in stage 1) and methane (in stage 2) from sucrose-rich by-products of the sugar beet refining industry as the primary energy substrates under mesophilic conditions. Recently, the two-stage system for hydrogen and methane production has been successfully scaled up 10-fold (a pilot scale) and currently operates in one of the Polish sugar factories. The efficiency of hydrogen and methane production were directly proportional to the scale of installation. The obtained results led to the development objectives of further research that the end result will be an innovative solution for the sugar factory as a producer of gaseous biofuels.
\end{abstract}

Keywords: anaerobic digestion, microorganisms, hydrogen, methane, molasses, up-scaling

\section{Introduction}

Anaerobic digestion of biomass under mesophilic conditions and whose final products are methane and

*e-mail: annaw@ibb.waw.pl

carbon dioxide contributes to the energy flow and circulation of matter in ecosystems. It is a key process in the global carbon cycle that is promoted by the activity of many different groups of microorganisms. Anaerobic digestion commonly occurs in natural anoxic ecosystems with a low redox potential, i.e., where concentrations of other electron acceptors, including nitrate and oxidized forms of metals such as $\mathrm{Mn}(\mathrm{IV})$ and $\mathrm{Fe}(\mathrm{III})$ or sulphate 
are low. Anaerobic digestion is common in landfill sites and anaerobic wastewater treatment plants [1-2].

The general scheme of anaerobic digestion is well known (Fig. 1). It is a complex process promoted by the interaction of many groups of microorganisms and has four major steps. The first is the hydrolysis of complex organic polymers to monomers. The second step is acidogenesis, which results in the formation of hydrogen and carbon dioxide as well as non-gaseous fermentation products, i.e., low-molecular-weight organic acids (short-chain fatty acids) and alcohols. In the third step, known as acetogenesis, these non-gaseous products are further oxidized to hydrogen, carbon dioxide, and acetate, mainly by syntrophic degradation processes. The fourth step is methanogenesis. The final two steps, acetogenesis and methanogenesis, are closely linked and involve syntrophic associations between hydrogenproducing acetogenic bacteria and hydrogenotrophic methanogens. These associations keep the hydrogen partial pressure sufficiently low to allow acetogenesis to become thermodynamically favorable. This process, referred to as interspecies electron transfer, is in fact a hydrogen/formate transfer. Acetate is a direct substrate for acetotrophic methanogens and can also be syntrophically oxidized to hydrogen and carbon dioxide [3-6].

Hydrogen-yielding fermentation is considered to be one of the most attractive alternative biological methods of hydrogen production. However, there are two major drawbacks: low productivity of the process and the formation of large amounts of environmentally unfriendly non-gaseous fermentation products [7-8]. The theoretical maximum hydrogen yield during Clostridium-type fermentation is 4 moles of hydrogen per mole of glucose, when all of the substrate is converted to acetic acid. In practice, this value is lower due to the formation of nongaseous products such as organic acids and alcohols. Effective biomethane production from non-gaseous fermentation products could make biological production of biohydrogen via fermentation economically attractive. Thus, for the purposes of biotechnology the idea of separation of hydrogenic (hydrolysis and acidogenesis) and methanogenic (acetogenesis and methanogenesis) steps under controlled conditions was arisen to favor biohydrogen and biomethane production, respectively. In the first stage, hydrogen-rich fermentation gas is produced, while in the second stage, the non-gaseous products of hydrogen fermentation act as substrates for methanogenic consortia. These two processes are carried out in separate bioreactors of different types with different $\mathrm{pH}$ conditions and hydraulic retention times.

The use of two-stage systems for hydrogen and methane production are reported in the literature. Such systems have shown promise at the laboratory and pilot scales using various substrates from pure carbohydrates to organic wastes, plant biomass, and by-products of the food industry [9-10].

Previously we developed a bench-scale two-stage anaerobic digestion system that produces hydrogen (in stage 1) and methane (in stage 2) from continuously supplied molasses - a sucrose-rich by-product of the sugar beet refining industry as the primary energy substrate under mesophilic conditions. Initially, hydrogen is generated via processes of acidogenesis in a 3-litre packed bed reactor (PBR) by a hydrogen-yielding microbial community fermenting molasses. The seed sludge inoculum was obtained from a eutrophic, meromictic lake. Subsequently, non-gaseous organic products from this first stage feed a 3.5-litre UASB reactor in which methane (biogas) is produced by a methane-yielding microbial community. The seed methanogenic inoculum was activated sludge from a municipal waste treatment plant. The hydrogen- and methane-yielding microbial communities were described on the molecular level [1112].

The aims of the study were (i) to demonstrate a 10fold enlarged (a pilot) installation producing hydrogen and methane from molasses, a by-product of the sugar industry, based on two-stage anaerobic digestion under mesophilic conditions; and (ii) to answer the question whether it is possible to gain a comparable performance of hydrogen- and methane-producing bioreactors in a bench-scale described before (3- and 3.5-litre bioreactors) [11-12] and in the pilot scale (30- and 50-litre bioreactors).

\section{Materials and Methods}

\section{Seed Sludge, Feed Composition, and Experimental Set-Up for Continuous Hydrogen and Methane Production}

Figs 2(a-b) show, respectively, a schematic diagram and a photograph of the installation producing hydrogen and methane as a result of a two-stage decomposition of molasses in a continuous system in Dobrzelin Sugar Factory (Krajowa Spółka Cukrowa S.A., Poland). Stage 1 of this system constituted two 30-liter-packed bed reactors (PBR) filled with various types of packing material. The cultivation medium was M9 medium [13] supplemented with molasses from the sugar factory. The organic loading rate (OLR) was $34.0 \pm 2.5 \mathrm{~g}$ COD (chemical oxygen demand) molasses/L. The medium was saturated with a stream of pure nitrogen (Air Products, Poland). The seed sludge inoculum was a 50-ml sample of the selected hydrogen-yielding micriobial community described before [11]. The tested packing materials

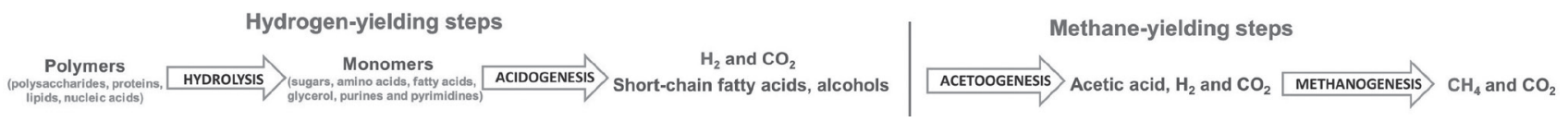

Fig. 1. Scheme of anaerobic digestion of polymeric organic matter to methane and carbon dioxide. 
a)

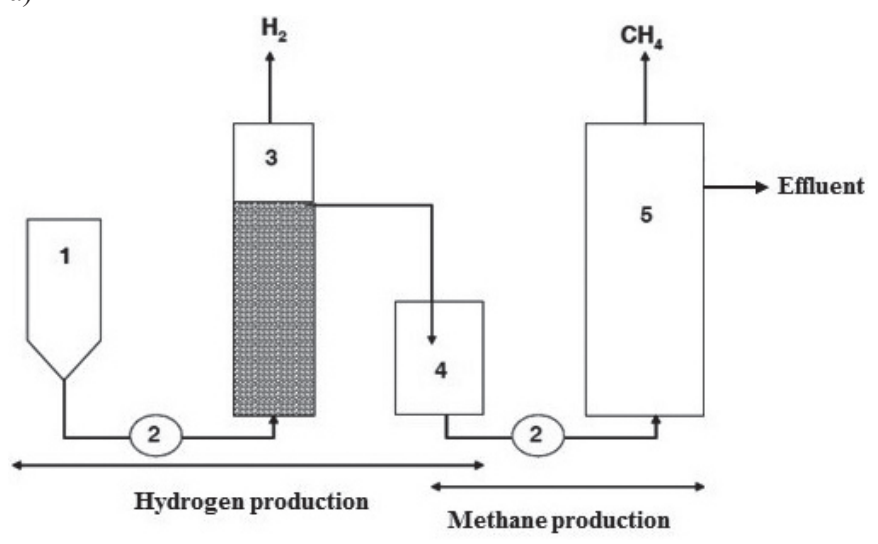

b)

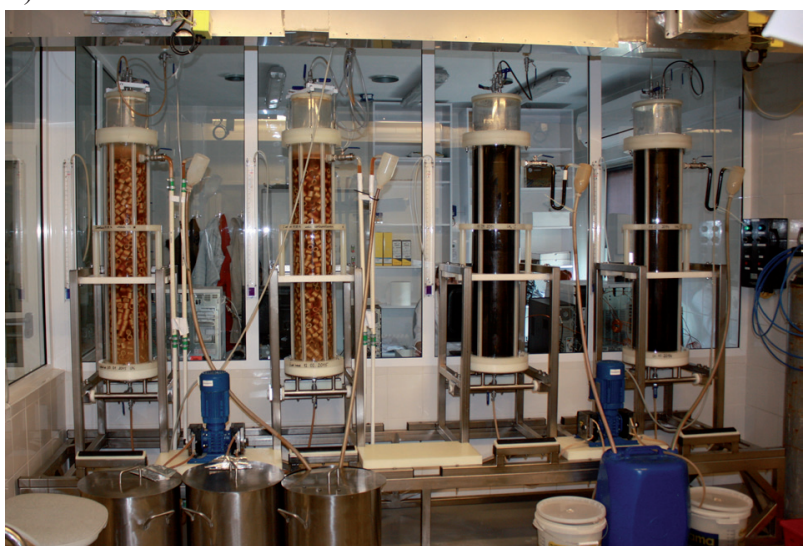

Fig. 2. The two-step installation producing hydrogen and methane by microorganisms as a result of two-stage anaerobic digestion of molasses in a continuous system: a) - a schematic diagram (1 - substrate; 2 - peristaltic pumps; 3 - packed bed reactor, stage 1 ; 4 - acidic effluent from stage 1; 5 - UASB reactor, stage 2); and b) - a photograph of the installation operating in Dobrzelin Sugar Factory (KSC S.A., Poland), from the left: two bioreactors of stage 1 and two bioreactors of stage 2 .

were: ceramic Raschig rings $(28 \mathrm{~mm} \mathrm{~L} \times 22 \mathrm{~mm}$ O.D. $\times 8 \mathrm{~mm}$ thick $)$ and pumice glass cubes $(2.9 \times 2.9$ $\times 2.9 \mathrm{~mm}$ ). It is well-recognized that the use of various packing materials in the reactors enhances granule formation and/or the biofilm attachment process that favors hydrogen production [14]. The bioreactors were put horizontally or vertically. The working volumes of the bioreactors were 17-20 L, depending on the type of packing material and bioreactor position. The medium flow was switched on several days after inoculation. The hydraulic retention time (HRT) was 13-17 h. The hydrogen-producing microbial community was renewed by removing the excess biomass every several weeks.

Stage 1 of the system was the source of acidic effluent being processed by a methane-yielding microbial community in stage 2 . Stage 2 constituted two 50-liter upflow anaerobic sludge blanket reactors (UASB). The seed methanogenic inoculum was activated sludge from the Warszawa Południe municipal waste treatment plant in Warsaw, Poland, sampled in September. The director of municipal water and sewage enterprise in the capital city of Warsaw in Poland issued the permission to sample activated sludge and use it for scientific research. The inoculation procedure was analogous to that described previously [12], taking into account the enlarged scale of the bioreactors. Substrates for hydrogen- and methaneyielding fermentations were supplied to bioreactors using peristaltic pumps (Rael Motori Elettrici, Italy). The acidic effluent from molasses fermentation was supplied to the UASB reactor continuously, the HRT was 140-180 hours. In some periods the effluent was neutralized with calcium hydroxide $(50 \mathrm{~g} / \mathrm{L})$ before processing to methane. The system is still operating in Dobrzelin Sugar Factory (KSC S.A.). The data presented in this paper come from the experiments done in the selected periods of the continuous monitoring of the bioreactors' performance during 12 months of operation.

At the same time the referring installation producing hydrogen and methane as a result of a two-stage decomposition of molasses in a continuous system in a bench-scale (3-litre PBR bioreactors in stage 1 and 3.5-litre UASB bioreactors in stage 2) were maintained. In stage 1 , the same inoculum, packing materials, HRTs and ORLs as described for 10-fold enlarged (pilot) installation were examined. Stage 2 was a continuation of the experiment described previously [12].

\section{Analytical Methods}

The total rate of gas production was measured using a bubble flowmeter (Zakłady Urządzeń Przemysłowych ZAM Kęty, Poland). The composition of fermentation gases was analyzed by gas chromatography GC/ TCD (gas chromatography with thermal conductivity detector) using an Agilent Technologies model 7890B gas chromatograph and by mass spectrometry (Hiden Analytical HPR 20).

The $\mathrm{pH}$ of the acidic effluent from molasses fermentation and the methanogenic effluent was measured using a standard $\mathrm{pH}$ meter (ELMETRON model CP-502, Poland). Samples of the acidic effluent from molasses fermentation and the methanogenic effluent were centrifuged and the chemical oxygen demand (COD), the concentrations of carbohydrates (sucrose, glucose and fructose), short-chain fatty acids and ethanol were determined. The chemical oxygen demand (COD) was determined using a NANOCOLOR COD 1500 kit (Machery-Nagel) according to ISO $1575: 2002$. The carbohydrates were analyzed using highperformance liquid chromatography (HPLC) with refractometric detection (Waters HPLC system: Waters 2695 - Separations Module, Waters 2414 - Refractive Index Detector, and $300 \times 6.5 \mathrm{~mm}$ Sugar Pak column with guard column). Short-chain fatty acids were analyzed by HPLC with photometric detection (Waters HPLC system as above, Waters 2996 - photodiode array detector, and $300 \times 7.8 \mathrm{~mm}$ Aminex HPX-87 H column with guard column). Ethanol was quantified by gas chromatography 
with flame-ionization detection (Hewlett Packard 6890, autosampler headspace - Hewlett Packard 7694E, polar 1.0- $\mu \mathrm{m}$ capillary column and FID). The HPLC conditions used for evaluating the levels of carbohydrates and organic acids were as described previously [11-12]. The molasses-containing medium was also examined.

In each case a mean \pm SD (standard deviation) were calculated.

\section{Results and Discussion}

Performance of the Two-Stage Installation Producing Hydrogen and Methane Based on Anaerobic Digestion of Molasses

A common problem in biotechnology is a drop in performance of biological processes caused by scaling up the bioreactor/installation system. The essence of scalingup is an elaboration of a suitable strategy in order to reach a similar volumetric productivity and efficiency of the enlarged process [15-16].

The specific objectives of the work were (i) to determine the efficiency of hydrogen and methane production depending on the scale of the installation (bench-scale vs. pilot-scale); (ii) testing various packing materials in the hydrogen-producing reactors (stage 1) for future applications; (iii) testing the position of the bioreactor (vertical vs. horizontal) in stage 1; and (iv) influence of neutralization of acidic effluent from molasses fermentation before the methanogenic step.

Regardless of the scale of bioreactors and the type of packing material, hydrogen-producing microbial communities formed granules and biofilms. Microscopic observations revealed various morphological forms of Gram-positive and Gram-negative bacteria. The microbial communities fed with the acidic effluent from molasses fermentation in bioreactors of both scales formed tiny, loose granules occupying up to $75 \%$ of the UASB bioreactor. The granular structure was a complex of morphologically varied microbial cells surrounded by a highly heterogeneous matrix rich in minerals (Fig. 2b, light micrographs not shown).

Table 1 specifies hydrogen and methane production in a two-stage anaerobic digestion of sugar beet molasses in various experimental approaches in a pilot-scale, i.e., 10-fold-enlarged installation (30- and 50-litre bioreactors for hydrogen and methane production, respectively). The experimental approaches included different packing materials used in PBR reactors; the position of a bioreactor (vertical vs. horizontal) in stage 1; and the influence of neutralization of acidic effluent from

Table 1. Performance of the 10-fold enlarged installation producing hydrogen and methane in the consecutive stages of anaerobic digestion of sugar beet molasses. In each case $n$ was given.

\begin{tabular}{|c|c|c|c|c|c|}
\hline \multicolumn{6}{|c|}{ Hydrogen production - Stage 1} \\
\hline Experimental & HRT (h) & $\begin{array}{l}\text { Fermentation gas } \\
\text { production } \\
\left(\mathrm{dm}^{3} / \text { day }\right)\end{array}$ & $\begin{array}{l}\text { Hydrogen } \\
\text { content } \\
(\%)\end{array}$ & $\begin{array}{l}\text { Carbon dioxide } \\
\text { content } \\
(\%)\end{array}$ & $\begin{array}{c}\text { Hydrogen } \\
\text { production } \\
\left(\mathbf{d m}^{3} / \mathrm{kg} \text { COD }\right. \\
\text { molasses })\end{array}$ \\
\hline $\begin{array}{c}\text { Raschig rings, vertical } \\
\text { position } \\
n=100\end{array}$ & $17.70 \pm 3.26$ & $142.17 \pm 33.67$ & $38.45 \pm 2.18$ & $57.8 \pm 2.81$ & $57.79 \pm 12.32$ \\
\hline $\begin{array}{l}\text { Raschig rings, horizontal } \\
\text { position } \\
n=23\end{array}$ & $13.29 \pm 4.49$ & $110.99 \pm 21.72$ & $39.53 \pm 2.15$ & $57.65 \pm 0.76$ & $60.91 \pm 9.99$ \\
\hline $\begin{array}{c}\text { pumice glass, vertical } \\
\text { position } \\
n=64\end{array}$ & $15.89 \pm 3.06$ & $149.72 \pm 29.14$ & $37.97 \pm 2.07$ & $59.78 \pm 1.96$ & $59.90 \pm 9.09$ \\
\hline $\begin{array}{c}\text { pumice glass, horizontal } \\
\text { position } \\
n=29\end{array}$ & $13,22 \pm 2.52$ & $174.44 \pm 44.04$ & $36.60 \pm 1.78$ & $60.38 \pm 1.94$ & $59.06 \pm 11.59$ \\
\hline \multicolumn{6}{|c|}{ Methane production - Stage 2} \\
\hline $\begin{array}{l}\text { Experimental } \\
\text { conditions }\end{array}$ & HRT (h) & $\begin{array}{l}\text { Fermentation gas } \\
\text { production } \\
\left(\mathrm{dm}^{3} / \text { day }\right)\end{array}$ & $\begin{array}{l}\text { Methane } \\
\text { content } \\
(\%)\end{array}$ & $\begin{array}{l}\text { Carbon dioxide } \\
\text { content } \\
(\%)\end{array}$ & $\begin{array}{c}\text { Methane } \\
\text { production } \\
\left(\mathbf{d m}^{3} / \mathrm{kg} \text { COD }\right. \\
\text { molasses })\end{array}$ \\
\hline $\begin{array}{l}\text { Neutralization of acidic } \\
\text { effluent } \\
n=168\end{array}$ & $141.84 \pm 48.29$ & $131.60 \pm 45.46$ & $66.28 \pm 6.45$ & $29.79 \pm 2.30$ & $282.63 \pm 84.93$ \\
\hline $\begin{array}{c}\text { Without neutralization of } \\
\text { acidic effluent } \\
n=46\end{array}$ & $161.33 \pm 29.01$ & $232.32 \pm 41.78$ & $59.91 \pm 4.48$ & $35.85 \pm 3.42$ & $323.94 \pm 81.01$ \\
\hline
\end{tabular}


Table 2. Hydrogen and methane production as a result of two-stage anaerobic digestion of sugar beet molasses in a bench-scale and the 10 -fold enlarged bioreactors. The table also shows data from similar studies reported in the scientific literature.

\begin{tabular}{|c|c|c|c|}
\hline Substrate & Hydrogen production & Methane production & Ref. \\
\hline $\begin{array}{c}\text { Sugar beet molasses in a } \\
\text { bench-scale }\end{array}$ & $\begin{array}{c}\text { 54.3-68.6 } \mathbf{d m}^{3} \mathbf{H}_{2} / \mathrm{kg} \text { COD molasses } \\
\text { 1.6-2.2 } \mathrm{dm}^{3} \mathrm{H}_{2} / \mathrm{L} \text { working volume } \\
\text { of the bioreactor /day }\end{array}$ & $\begin{array}{c}\text { 243-306 } \mathbf{~ m}^{3} \mathbf{C H}_{4} / \mathrm{kg} \text { COD molasses } \\
1.4-1.8 \mathrm{dm}^{3} \mathrm{CH}_{4} / \mathrm{L} \text { working volume } \\
\text { of the bioreactor / day }\end{array}$ & $\begin{array}{l}\text { This } \\
\text { study }\end{array}$ \\
\hline $\begin{array}{l}\text { Sugar beet molasses in a } \\
\text { pilot-scale }\end{array}$ & 57.8-60.9 dm $^{3} \mathrm{H}_{2} / \mathrm{kg}$ COD molasses & 282.6-323.9 $\mathrm{dm}^{3} \mathrm{CH}_{4} / \mathrm{kg}$ COD molasses & $\begin{array}{l}\text { This } \\
\text { study }\end{array}$ \\
\hline Cane molasses & $\begin{array}{c}2.8 \mathrm{~L} \mathrm{H}_{2} / \mathrm{L} \text { working volume of the bioreactor } \\
\text { / day }\end{array}$ & $\begin{array}{c}1.48 \mathrm{~L} \mathrm{CH}_{4} / \mathrm{L} \text { working volume of the } \\
\text { bioreactor / day }\end{array}$ & [9] \\
\hline Corn stalks & $58 \mathrm{~L} \mathrm{H}_{2} / \mathrm{kg}$ substrate & $200 \mathrm{~L} \mathrm{CH}_{4} / \mathrm{kg}$ substrate & {$[19]$} \\
\hline
\end{tabular}

molasses fermentation on methane production in stage 2. The examined types of the tested packing material does not change the efficiency of hydrogen production in stage 1 . The horizontal position of the bioreactor in stage 1 does not decrease hydrogen production in the tested experimental installation. It is promising and important for construction of the future industrial installation. Moreover, a horizontally positioned bioreactor supplies better conditions for hydrogen-rich fermentation gas released from the bioreactor. It is widely recognized that higher partial hydrogen pressure inhibits activity of the key enzymes for hydrogen production, pyruvate:ferredoxin oxidoreductase (PFOR) and NADH:ferredoxin oxidoreductase (NFOR), and favors the formation of non-gaseous end-products from acetyl-CoA, including butyrate, ethanol, butanol, and lactate [17-18].

As noted previously [12], neutralization of acidic effluent from molasses fermentation is necessary for the adaptation of the microbial community to the specific substrate, although finally it had no effect on the efficiency of methane production.
A comparable performance of hydrogen- and methane-producing bioreactors in a bench and the 10 -fold enlarged installation was achieved. Table 2 presents a general summary of hydrogen and methane production in consecutive stages of anaerobic digestion of sugar beet molasses in both scales tested in this study. The efficiencies of hydrogen and methane production were maintained in the same ranges in both scales. The amounts of hydrogen and methane were directly proportional to bioreactor size. The advantage of the processes presented here is no requirement for aeration and mixing. Furthermore, the processes are based on the selected microbial communities, not on pure strains, which makes the scaling-up procedure easier [15-16].

Table 2 also contains the data obtained for cane molasses and corn stalks by other groups that are comparable to ours.

Table 3 summarizes the characteristics of the acidic effluent resulting from molasses fermentation in stage 1 and the effluent from the methanogenic process (stage 2) in the 10-fold-enlarged installation supplied with

Table 3. Characteristics of the three liquids produced for or by the two-stage system in the enlarged two-stage installation.

\begin{tabular}{|c|c|c|c|}
\hline Parameter & $\begin{array}{c}\text { Molasses-containing } \\
\text { medium }\end{array}$ & $\begin{array}{c}\text { Acidic effluent from molasses } \\
\text { fermentation (Stage 1) }\end{array}$ & $\begin{array}{c}\text { Effluent from methanogenic } \\
\text { process (Stage 2) }\end{array}$ \\
\hline COD $\left(\mathrm{g} \mathrm{O}_{2} / \mathrm{L}\right)$ & $34.0 \pm 2.5$ & $24.3 \pm 5.4$ & $3.0 \pm 0.6$ \\
\hline \multicolumn{2}{|c|}{ Concentrations of: } \\
\hline Sucrose (g/L) & $20.4 \pm 1.5$ & $0.6 \pm 0.5$ & 0 \\
\hline Glucose (g/L) & $0.14 \pm 0.07$ & $0.08 \pm 0.08$ & 0 \\
\hline Fructose (g/L) & $0.17 \pm 0.16$ & $0.45 \pm 0.13$ & $1-200$ \\
\hline Formic acid (mg/L) & $84.3 \pm 18.0$ & $8-300$ & $500-1,300$ \\
\hline Acetic acid (mg/L) & $722 \pm 60$ & $1,000-2,500$ & $5-400$ \\
\hline Butyric acid (mg/L) & $142 \pm 3.5$ & $6,000-8,500$ & $30-100$ \\
\hline Isobutyric acid (mg/L) & $107.3 \pm 21.8$ & $400-1,000$ & $<1-20$ \\
\hline Lactic acid (mg/L) & $1083 \pm 29.5$ & $400-1,500$ & $500-2,000$ \\
\hline Propionic acid (mg/L) & $468 \pm 66.4$ & $500-1,000$ & $2-40$ \\
\hline Ethanol (mg/L) & $0.013 \pm 0.004$ & $100-800$ & $6.50-7.65$ \\
\hline pH & 7.00 & $4.50-5.20$ & \\
\hline
\end{tabular}


molasses at concentrations of about $34 \mathrm{~g} \mathrm{COD/L}$. Due to the comparable concentrations of the specific compounds in the respective effluents, the data were presented together. The overall COD removal efficiency of the twostage process was about $91 \%$. The $\mathrm{pH}$ is a very important factor in ensuring the stability of both processes. The $\mathrm{pH}$ values of the effluents indicate the conditions in the bioreactors. Butyric acid was the main non-gaseous product of the hydrogen-yielding step and the most efficiently used substrate by the methane-yielding microbial community. Efficient utilization of lactic acid and ethanol in the second stage of the process was also observed.

We have previously shown that in stage 1 of the bench-installation [11-12] the dominant bacteria were representatives of the Clostridiaceae, Enterobacteriaceae, and heterolactic fermentation bacteria, mainly Leuconostocaeae. Our own research and the findings of other groups indicate that a phenomenon analogous to cross-feeding observed in the gastrointestinal tract may occur in hydrogen-producing bioreactors and natural environments. Cross-feeding involves lactate and acetate conversion to butyrate and hydrogen by butyrateproducing intestinal bacteria, stimulated by lactic acid bacteria $[20]$.

\section{Perspectives for Biohydrogen and Biomethane (Biogas) Production in the Consecutive Stages of Anaerobic Digestion of Molasses}

Methane (biogas) is commonly used for energy in many countries, including Poland. After passing through the biogas purification system the biogas can be used as fuel in the co-generator where electrical power and heat are produced for specific needs. Hydrogen is not currently used on a large scale as an energy carrier. However, its advantages as such a carrier predestine it for wide application. The most efficient way of converting the chemical energy of molecular hydrogen to useful, non-thermal energy is via the use of fuel cells, which are electrochemical converters of chemical energy. In principle, such conversion does not involve heat transfer processes. The chemical energy is directly transformed into electricity. Thanks to this, the theoretical efficiency of fuel cells under the relevant temperature and pressure conditions is much higher than the efficiency of heat engines. The maximum hydrogen fuel cell efficiency is over two times higher than the maximum efficiency of a heat engine burning hydrogen. For this reason, fuel cells are envisioned as the engines of the future hydrogen economy. However, conventional methods of hydrogen production are based on fossil fuel.

Hydrogen-yielding fermentation processes are considered among alternative methods of hydrogen production. Previously, a series of successful experiments of supplying a polymer electrolyte membrane fuel cell with air and a hydrogen-rich gas obtained by microbial fermentation of molasses was conducted [21]. The hydrogen-rich gas came from the two-stage installation described here.

Taking into account the Earth's finite fossil fuel resources, global warming and directives on the limitation of carbon dioxide emissions, the data suggest that this two-stage process holds promise for industrialscale production of biohydrogen and biomethane, from by-products of the sugar refining industry, that could be used for future energy generation.

\section{Conclusions}

The obtained results gave a positive answer to the question of whether it is possible to gain a comparable performance of hydrogen- and methane-producing bioreactors in a bench-scale and a pilot-scale. We have obtained directly proportional production of hydrogen and methane in the 10-fold enlarged installation in comparison to the previously described bench-scale and thereby the similar efficiencies of hydrogen and methane production in both scales.

The obtained results describing the performance of a pilot-scale installation generating hydrogen and methane in a two-stage process led to the development objectives of further research. The main expected result of the new project will be an innovative solution for the sugar factory as a producer of the biofuels biohydrogen and biomethane from bio-waste and by-products of the sugar industry. The key to success will be the transformation of the pilotscale installation results to the industrial-scale process.

\section{Acknowledgements}

We acknowledge the support of the National Centre for Research and Development, Poland, through grant PBS1/B9/9/2012 awarded for 2012-16, and grant BIOSTRATEG2/297310/13/NCBiR/2016 awarded for 2016-19.

We would like to thank Emilia Gajewska, Ewa Wiktorowska-Sowa, Dorota Jaźwińska, Anna Furman, Małgorzata Bielicka, and Błażej Kuras from the Dobrzelin Sugar Factory (KSC SA, Poland) for their technical assistance, and Professor Piotr Piela for critical discussion.

\section{References}

1. THAUER R.K., KASTER A.-K., SEEDORF H., BUCKEL W., HEDDERICH R. Methanogenic Archaea: ecologically relevant differences in energy conservation. Nat. Rev. Microbiol. 6 (8), 579, 2008.

2. LIU Y., WHITMAN W. B. Metabolic, phylogenetic, and ecological diversity of the methanogenic archaea. Ann. N Y Acad. Sci. 1125 (1), 171, 2008.

3. DEMIREL B., SCHERER P. The roles of acetotrophic and 
hydrogenotrophic methanogens during anaerobic conversion of biomass to methane: a review. Rev. Environ. Sci. Biotechnol. 7 (2), 173, 2008.

4. STAMS A.J.M., PLUGGE C.M. Electron transfer in syntrophic communities of anaerobic bacteria and archaea. Nat. Rev. Microbiol. 7 (8), 568, 2009.

5. SIEBER J.R., McINERNEY M.J., GUNSALUS R.P. Genomic insight into syntrophy: the paradigm for anaerobic metabolic cooperation. Annu. Rev. Microbiol. 66, 429, 2012.

6. LEE S.-H., PARK J.-H., KIM S.-H., YU B.J., YOON J.-J., PARK H.-D. Evidence of syntrophic acetate oxidation by Spirochaetes during anaerobic methane production. Bioresour. Technol. 190, 543, 2015.

7. HALLENBECK P.C., GHOSH D. Advances in fermentative biohydrogen production: the way forward? Trends Biotechnol. 27 (5), 287, 2009.

8. LEE H.S, VERMAAS W.F.J., RITTMANN B.E. Biological hydrogen production: prospects and challenges. Trends Biotechnol. 28 (5), 262, 2010.

9. PARK M.J., JO J.H., PARK D., LEE D.S., PARK J.M. Comprehensive study on a two-stage anaerobic digestion process for the sequential production of hydrogen and methane from cost-effective molasses. Int. J. Hydrogen Energy 35 (12), 6194, 2010.

10. GUWY A.J., DINSDALE R.M., KIM J.R., MASSANETNICOLAU J., PREMIER G. Fermentative biohydrogen production systems integration. Bioresour. Technol. 102 (18), 8534, 2011.

11. CHOJNACKA A., SZCZECSNY P., BŁASZCZYK M.K., ZIELENKIEWICZ U., DETMAN A., SALAMON A., SIKORA A. Noteworthy acts about a methane-producing microbial community processing acidic effluent from sugar beet molasses fermentation. PLoS One 10 (5), e0128008, 2015.

12. CHOJNACKA A., BŁASZCZYK M.K., SZCZECNY P., NOWAK K., SUMIŃSKA M., TOMCZYK-ŻAK K., ZIELENKIEWICZ U., SIKORAA. Comparative analysis of hydrogen-producing bacterial biofilms and granular sludge formed in continuous cultures of fermentative bacteria. Bioresour. Technol. 102 (21), 10057, 2011.

13. MILLER J.H. Experiments in Molecular Genetics. Cold Spring Harbor Laboratory, Cold Spring Harbor, NY, USA, 431, 1972.

14. LI C., ZHANG T., FANG H.H. Fermentative hydrogen production in packed-bed and packing-free upflow reactors. Water Sci. Technol. 54 (9), 95, 2006.

15. SCHMIDT F.R. Optimization and scale up of industrial fermentation processes. Appl. Microbiol. Biotechnol. 68 (4), 425, 2005.

16. FORMENTI L.R., NORREGAARD A., BOLIC A., HERNANDEZ D.Q., HAGEMANN T., HEINS A.-L., LARSSON H., MEARS L., MAURICIO-IGLESIAS M., KRUHNE U., GERNAEY K.V. Challenges in industrial fermentation technology research. Biotechnol. J. 9 (6), 727, 2014.

17. HALLENBECK P.C. Fundamentals of the fermentative production of hydrogen. Water Sci. Technol. 52 (1-2), 21, 2005.

18. KRAEMER J.T., BAGLEY D.M. Improving the yield from fermentative hydrogen production. Biotechnol. Lett. 29 (5), 685, 2007.

19. CHENG X.Y., LI Q., LIU C.Z. Coproduction of hydrogen and methane via anaerobic fermentation of cornstalk waste in continuous stirred tank reactor integrated with up-flow anaerobic sludge bed. Bioresour. Technol. 114, 327, 2012.

20. SIKORA A., BŁASZCZYK M.K., JURKOWSKI M., ZIELENKIEWICZ U. Lactic acid bacteria in hydrogen producing consortia: on purpose or by coincidence. In Lactic acid bacteria - R \& D for food, health and livestock purposes. M. Kongo, Ed., InTech, Rijeka, 487, 2013.

21. PIELA P., TOKARZ W., KAŹMIERCZAK W., DETMAN A., SIKORA A., PIOTROWSKI J. The use of hydrogen-rich gas obtained from dark fermentation of molasses from sugar industry for fueling a fuel cell. Przemysl Chemiczny 95 (5), 1000, 2016. 
